\title{
Correction to: Central composite design for the development of carvedilol-loaded transdermal ethosomal hydrogel for extended and enhanced anti-hypertensive effect
}

Padmanabha Rao Amarachinta ${ }^{1 \dagger}$, Garima Sharma ${ }^{2 \dagger}$, Noufel Samed $^{2 \dagger}$, Ananda Kumar Chettupalli ${ }^{1}$, Madhusudhan Alle $2^{2^{*}}$ and Jin-Chul Kim ${ }^{2^{*}}$ (1)

\section{Correction to: J Nanobiotechnol (2021) 19:100}

https://doi.org/10.1186/s12951-021-00833-4

Following publication of the original article [1], the authors identified a change in the 'Funding' section. The complete 'Funding' section is given below

"This research was supported by Technology Innovation Program (20009663) funded by the Ministry of Trade, Industry \& Energy (MOTIE, Korea). This research was also supported by Basic Science Research Program through the National Research Foundation of Korea (NRF) funded by the Ministry of Education (No. 2018R1A6A1A03025582)." The original article has been revised.

\section{Reference}

1. Amarachinta PR, Sharma G, Samed N, Chettupalli AK, Alle M, Kim JC. Central composite design for the development of carvedilol-loaded transdermal ethosomal hydrogel for extended and enhanced anti-hypertensive effect. J Nanobiotechnol. 2021;19:100. https://doi.org/10.1186/ s12951-021-00833-4.

\section{Publisher's Note}

Springer Nature remains neutral with regard to jurisdictional claims in published maps and institutional affiliations.

\section{Author details}

${ }^{1}$ School of Pharmacy, Anurag University, Telangana 500088, India. ${ }^{2}$ Department of Biomedical Science \& Institute of Bioscience and Biotechnology, Kangwon National University, Chuncheon 24341, Republic of Korea.

Published online: 19 July 2021

The original article can be found online at https://doi.org/10.1186/s12951021-00833-4.

\footnotetext{
*Correspondence: allemadhusudhan@kangwon.ac.kr; jinkim@kangwon.ac.kr

†PadmanabhaRao Amarachinta, Garima Sharma and Noufel Samed

contributed equally to this work

${ }^{2}$ Department of Biomedical Science \& Institute of Bioscience

and Biotechnology, Kangwon National University, Chuncheon 24341, Republic of Korea

Full list of author information is available at the end of the article
}

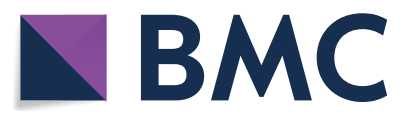

(c) The Author(s) 2021. This article is licensed under a Creative Commons Attribution 4.0 International License, which permits use, sharing, adaptation, distribution and reproduction in any medium or format, as long as you give appropriate credit to the original author(s) and the source, provide a link to the Creative Commons licence, and indicate if changes were made. The images or other third party material in this article are included in the article's Creative Commons licence, unless indicated otherwise in a credit line to the material. If material is not included in the article's Creative Commons licence and your intended use is not permitted by statutory regulation or exceeds the permitted use, you will need to obtain permission directly from the copyright holder. To view a copy of this licence, visit http://creativeco mmons.org/licenses/by/4.0/. The Creative Commons Public Domain Dedication waiver (http://creativecommons.org/publicdomain/ zero/1.0/) applies to the data made available in this article, unless otherwise stated in a credit line to the data. 